\title{
Performance Assessment of Irrigation Schemes and Water Pollution Issues Raised in the Red River, Vietnam
}

\author{
Nguyen Duc Viet ${ }^{1, *}$, Dao Trong Tu ${ }^{2}$, Nguyen Tung Phong ${ }^{3}$, Ha Hai Duong ${ }^{4}$ \\ ${ }^{1}$ Directorate of Water Resources - Ministry of Agriculture and Rural Development, DWR, Hanoi, Vietnam \\ ${ }^{2}$ Centre for Sustainable Water Resources and Climate Change, CSWRCC, Hanoi, Vietnam \\ ${ }^{3}$ Vietnam Academy for Water Resources, VAWR, Hanoi, Vietnam \\ ${ }^{4}$ Institute for Water and Environment, IWE, Hanoi, Vietnam
}

Email address:

vietnd@wrd.gov.vn (N. Duc Viet), tu.daotrong2013@gmail.com (D. T. Tu), phongicd@gmail.com (N. T. Phong),

hahaiduongcwe@yahoo.com (H. H. Duong)

${ }^{*}$ Corresponding author

\section{To cite this article:}

Nguyen Duc Viet, Dao Trong Tu, Nguyen Tung Phong, Ha Hai Duong. Performance Assessment of Irrigation Schemes and Water Pollution Issues Raised in the Red River, Vietnam. International Journal of Environmental Protection and Policy. Vol. 6, No. 1, 2018 , pp. 1-8. doi: 10.11648/j.ijepp.20180601.11

Received: November 27, 2017; Accepted: December 11, 2017; Published: January 10, 2018

\begin{abstract}
Irrigation schemes management in Red River Delta, Northern Vietnam has an extreme significance to ensure the multi-objective water supply and the health of the Red River. This study is drawn upon mostly primary data sources including results of water supply assessment of economic industries and the status quo of hydraulic works (pumping station, canals, gates, regulating reservoirs, etc.) along the Red river (study area inside the territory of Vietnam), then compare the results against the value of water supply capacity of irrigation schemes in the context of effectiveness of hydraulic works has not yet achieved as original designs (approximately 60\%). From that point, identifying the relationships between - trade off - the water supply and healthy of the Red river. The results of the comparison show that the water supply for agriculture production will increase dramatically in 2020 approximately from $8 \mathrm{bill.} \mathrm{m}^{3} /$ year compared to actual demand of about $13.65 \mathrm{bill} . \mathrm{m}^{3} /$ year. And, more irrigation water may be more harmful for the Red river's health, which is absolutely correct in the context of irrigation schemes also supply for other sectors such as industry, drinking water, aquaculture farms, etc. The results of this study are conclusive evidence to promote the implementation of a number of water policies in the Red River Delta.
\end{abstract}

Keywords: Performance Assessment of Irrigation Schemes, Water Pollution Issues, Water Resources Management, Water Resource Protection, Irrigation Schemes Management, Water Quality and Quantity, Red River Delta, Red River Basin

\section{Introduction}

Vietnam is a country located at downstream of major rivers, with 2,360 rivers, total reserve of surface water is estimated at about $830-840$ bill. $\mathrm{m}^{3}$, in which three-quarters of the water flowing from abroad into the territory [1]. Currently, the two largest river basins of Vietnam are Mekong River (South) and Red River (North).

According to Ministry of Natural Resources and Environment (MONRE) of Vietnam, Red River Basin (RRB) is approximately $169,020 \mathrm{~km}^{2}$, of which $81,240 \mathrm{~km}^{2}(48 \%)$ in China's territory, $1,100 \mathrm{~km}^{2}(0.65 \%)$ in Laos and $86,660 \mathrm{~km}^{2}$ (approximately 51.35\%) in Vietnam. Red river has a length of $1,149 \mathrm{~km}$, in which, the length in the territory of Vietnam is about $328 \mathrm{~km}$ [2].

Rivers have played an important role in the economics society development of human life, since thousands of years, before the irrigation schemes exist, many delta regions have been formed naturally by the floodplains of the river. And, Red River Delta (RRD) is one such delta (approximately 23,336 $\mathrm{km}^{2}$ ) [3], account for 7,1\% Vietnam's area.

The total amount of water of the Red River flowing to the territory of Vietnam has been estimated at about 82.54 bill. $\mathrm{m}^{3} /$ year [4], [5], it carries a large amounts of sediment 
estimated about 115 million tons/year [6], that has greatly contributed to the development of agricultural production.

In the RRD, the irrigation schemes is essential infrastructure, serving agricultural production, contributing to significantly increases productivity, yield and quality of agricultural products, fisheries, supplying water for people's living and other economic sectors, drainage, contributing to prevention and mitigation of damage caused by natural disasters, and promoting socio-economic development. So far, with the huge investment of the State, the contributions of the people and the international organizations, the RRD has 140 dams, 500 reservoirs of different types and 5,500 pumping stations which are nodal taking water from the Red river for transmission and distribution through $61,300 \mathrm{~km}$ of canals of all levels (levels 1, 2, 3 and on-farm) [7]. The RRD also has some large irrigation schemes as Bac Hung Hai (110,000ha of irrigated area) and Bac Nam Ha $(59,000$ ha of irrigated area and 86,000 ha of drainage area) [8]. This system is considered "blood vessel" for development of 10 provinces in RRD with nearly 20 million people living [9].

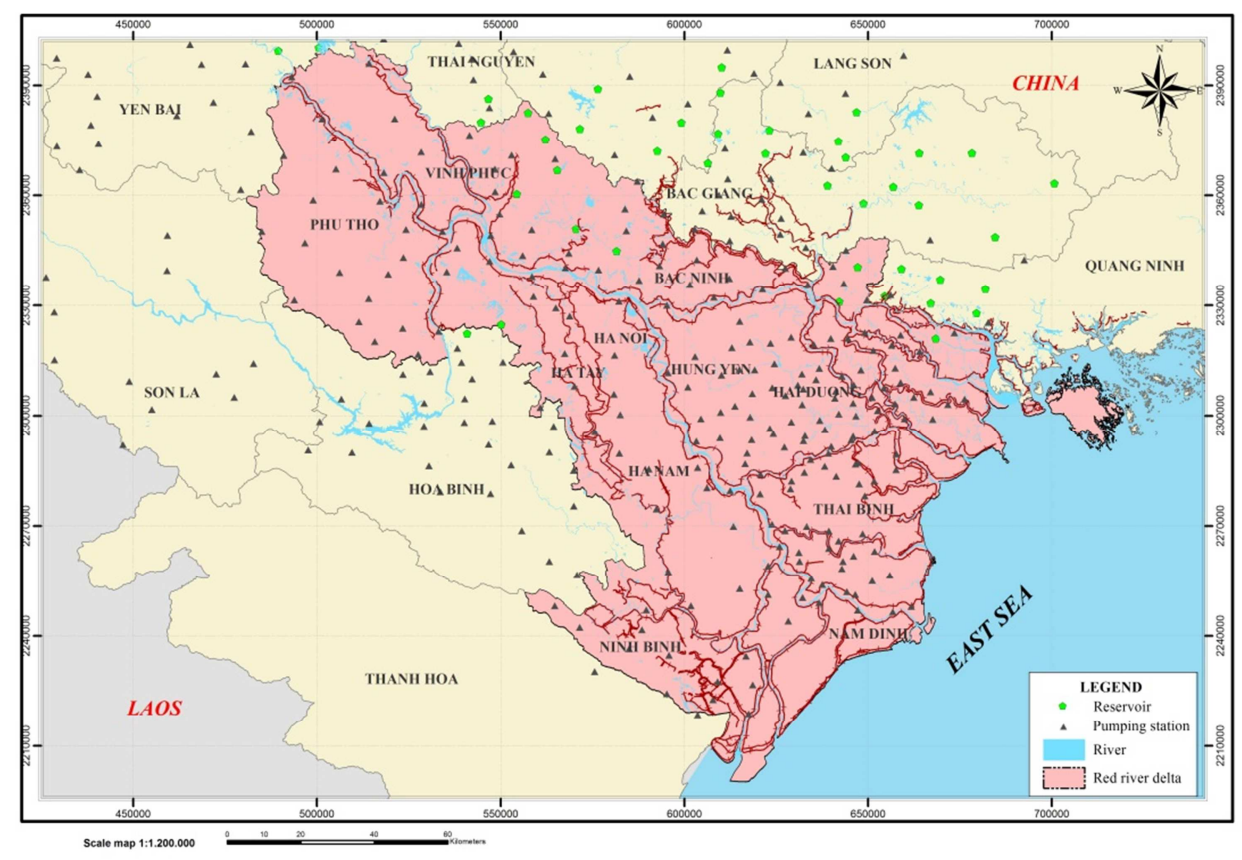

Figure 1. Red river and Red River Delta in Vietnam.

According to forecasts by 2020 of the previous researches [10]-[12], the capacity of the irrigation schemes in RRD will not be enough to meet domestic demand for the economic sectors due to low effectiveness of management and exploitation of irrigation works. Some main reasons are: (i) management institution of RRB; (ii) the degradation of the irrigation works; and (iii) regime of deficiency funding of irrigation fees. Anticipated consequences of irrigation water shortage by 2020 combining with the negative impacts of climate change and sea level rise will cause serious impacts to the development of agricultural production and other economic sectors such as industry, transport waterway, tourism, etc. leading to the degradation of the aquatic ecosystem and local people's livelihood of the Red River.

In this research, first step is determine the water demand at the research time (2015) and forecasts up to 2020, then, compare this results with the water supply capacity of all the irrigation schemes of the Red River Delta. The irrigation schemes efficiency assessment will be implemented through the Benchmarking Index (including 22 indicators), then, these results will be discussed before proposing specific policies regarding management of irrigation schemes for the RRD.

\section{Research Methods}

\subsection{SWOT Analysis Method}

SWOT is the abbreviation of Strengths - Weaknesses Opportunities - Threats. SWOT analysis is a very effective tool to determine the advantages and disadvantages of a policy, both opportunities, challenges and risks that such policies must face when it is established (Table 1) [13]. Based on the results analysis, managers (national or regional level) will make the appropriate policy choices.

Table 1. SWOT analysis template.

\begin{tabular}{lll}
\hline & Strengths & Weaknesses \\
Internal & 1. & 1. \\
& 2. & 2. \\
& 3. & 3. \\
& $\ldots$ & $\ldots$ \\
External & Opportunities & Threats \\
& 1. & 1. \\
& 2. & 2. \\
& 3. & 3. \\
\hline
\end{tabular}

Source: International Journal of Innovative and Applied Research, 2014. 


\subsection{Method of Water Demand Calculation}

Demand for water use is the total water required of economic sectors such as crops, breeding, aquaculture, industry, and living and environment, etc; speciffically as follows:

\subsubsection{Water Demand for Crops}

Water demand for crops is calculated by CROWAT software. Evapotranspiration of crop (ETc) is calculated by the formula:

$$
\mathrm{ET}_{\mathrm{c}}=\mathrm{K}^{\mathrm{c}} \times \mathrm{ET}^{\mathrm{o}}(\mathrm{mm} / \text { day })
$$

In which:

i) $\mathrm{ET}^{\mathrm{o}}$ : Potential evapotranspiration, is calculated by the formula of Penmam - Monteith.

ii) $\mathrm{K}^{\mathrm{c}}$ : Crop coefficient, is identified in Table 2.

Table 2. Determination of growth-stage crop coefficients.

\begin{tabular}{llllll}
\hline \multirow{2}{*}{ Crop } & \multicolumn{6}{l}{ Growth stage specific crop coefficients } \\
\cline { 2 - 6 } & Begin & Growth & Middle & End & Growth \\
\hline Rice & $1.1-1.15$ & $1.1-1.3$ & $1.1-1.35$ & $1.05-1.3$ & $0.95-1.05$ \\
Potato & $0.4-0.5$ & $0.7-0.9$ & $1.05-1.2$ & $0.8-1.05$ & $0.7-0.8$ \\
Peanut & $0.4-0.5$ & $0.7-0.85$ & $0.95-1.1$ & $0.95-0.8$ & $0.85-0.7$ \\
Sugar & $0.4-0.5$ & $1.05-1.1$ & $1.05-1.1$ & $0.8-0.95$ & $0.8-0.9$ \\
\hline
\end{tabular}

Source: Institute for Waterand Environment, 2014

\subsubsection{Water Demand for Breeding}

Water demand for breeding: in accordance with standards of Ministry of Construction of Vietnam in 2020 for:

i) Residents in rural areas is 70 (1/day/person).

ii) Residents in urban areas is 120 (1/day/person).

iii) Buffalo, cattle is 135 ( $1 /$ day/unit); pig is 60 ( $1 /$ day/unit) and poultry is 11 (1/day/unit).

\subsubsection{Water Demand for Fishery}

Water demand for fishery: this demand depends on the form of fisheries:

i) Freshwater aquaculture: including in rivers and reservoirs, two of this type do not need freshwater.

ii) Aquaculture in ponds: needs regular supply of fresh water for deacidification and creating environment for aquatic growth and development.

Deacidification water is calculated by the equation as follows:

$$
\mathrm{W}=10 \times\left(\mathrm{a}_{\mathrm{i}}+\mathrm{E}_{\mathrm{i}}\right)\left(\mathrm{m}^{3} / \mathrm{ha}\right)
$$

In which:

W: Deacidification water of each month $\left(\mathrm{m}^{3} / \mathrm{ha}\right)$;

$\mathrm{a}_{\mathrm{i}}$ : Water layer needs to be replaced $(\mathrm{mm})$;

$\mathrm{E}_{\mathrm{i}}$ : Evaporation amount between 02 times of the water changes (mm).

On average, in the Red River Delta, water demand for aquaculture is estimated at $8,000-12,000 \mathrm{~m}^{3} /$ ha/year.

\subsubsection{Water Demand for Industry}

Water demand for industry: for concentrated industrial zones, the amount of water is calculated at $(50-80) \mathrm{m}^{3} /$ ha/day or by specific products:

i) Food industry: 1,000 $\mathrm{m}^{3} / 1,000 \mathrm{USD}$.

ii) Light industry: $400 \mathrm{~m}^{3} / 1,000$ USD

iii) Heavy industry: $200 \mathrm{~m}^{3} / 1,000$ USD

\subsubsection{Water Demand for Drinking Water}

Water demand for drinking water: depends on each area, specifically as following:

i) Urban area: in the city is 150 ( $1 /$ person/day) and suburban is $100(1 /$ person/day).

ii) Rural area: 60 (1/person/day).

\subsubsection{Water Demand for Environmental Flow}

Environmental flow is water demand for ecological environment is the amount of water used for processing, dilution of the effluent from the water demand for crops, breeding, living, industries and aquaculture.

Therefore, to maintain the environmental flow of the river basin in the development phase until 2020, it will need $15-20 \%$ of the water demand for irrigation throughout the Red River Basin.

\subsection{Methods of Performance Assessment of Irrigation Scheme Management}

Applying the assessment of irrigation schemes in RRD by the Benchmarking Evaluation Index, including 22 indicators and 29 component parameters [14].

The meaning of each indicators as Table 3 .

\begin{tabular}{|c|c|}
\hline \multicolumn{2}{|c|}{ Construction management criteria (C) } \\
\hline $\mathrm{C} 1$ & Cost for operating, maintenance and repairs (VNĐ/ha) \\
\hline $\mathrm{C} 2$ & Rate of solidification canals $(\%)$ \\
\hline $\mathrm{C} 3$ & Water monitoring $(\%)$ \\
\hline $\mathrm{C} 4$ & Construction saftify $(\%)$ \\
\hline \multicolumn{2}{|c|}{ Water management criteria $(\mathrm{N})$} \\
\hline N1 & Irrigation levels $\left(\mathrm{m}^{3} / \mathrm{ha}\right)$ \\
\hline N2 & On-farm irrigation water use $\left(\mathrm{m}^{3} / \mathrm{ha}\right)$ \\
\hline N3 & Efficient agricultural water use (VNĐ/ha) \\
\hline N4 & Irrigation efficiency compare with original designs (\%) \\
\hline N5 & Irrigation efficiency compare with plan (\%) \\
\hline N6 & External demand for agricultural production (\%) \\
\hline N7 & Drainage efficiency for agriculture (\%) \\
\hline \multicolumn{2}{|c|}{ Economic management criteria $(\mathrm{K})$} \\
\hline $\mathrm{K} 1$ & Number of labor management (ha/person) \\
\hline $\mathrm{K} 2$ & $\begin{array}{l}\text { Management skills of Irrigation and Drainage Management } \\
\text { Company (IDMC) }(\%)\end{array}$ \\
\hline $\mathrm{K} 3$ & Management skills of workers (\%) \\
\hline K4 & The cost ratio of irrigation scheme (\%) \\
\hline K5 & The cost ratio of labor of irrigation scheme (\%) \\
\hline K6 & $\begin{array}{l}\text { The cost ratio of operation and maintenance of an irrigation } \\
\text { scheme }(\%)\end{array}$ \\
\hline \multicolumn{2}{|c|}{ Water environment management criteria $(\mathrm{M})$} \\
\hline M1 & Irrigation water quality \\
\hline \multicolumn{2}{|c|}{ Water user organization management criteria $(\mathrm{T})$} \\
\hline T1 & Density of on-field channel $(\mathrm{km} / \mathrm{ha})$ \\
\hline $\mathrm{T} 2$ & Farmers participation in water management (VNĐ/ha) \\
\hline $\mathrm{T} 3$ & The cost ratio of water fee subsidy of WUO (\%) \\
\hline T4 & The cost ratio of water fee collection $(\%)$ \\
\hline
\end{tabular}

Table 3. Meanings of Benchmarking indicators.

Source: Decision No. 2212/QĐ-BNN-TCTL, MARD Vietnam. 


\section{Research Results}

\subsection{Water Demand Calculation Results}

The calculation results for water consumption of major economic sectors in RRD as Table 4.

Table 4. Water demand forecast of RRD by 2020.

\begin{tabular}{|c|c|c|}
\hline No. & Water Demand Forecast to 2020 & \\
\hline A & Water consumption & \\
\hline 1 & Agriculture & 13.65 bill. $\mathrm{m}^{3} /$ year \\
\hline 2 & Drinking water & 1.15 bill. $\mathrm{m}^{3} /$ year \\
\hline 3 & Industry, handicraft villages & 0.55 bill. $\mathrm{m}^{3} /$ year \\
\hline 4 & Livestock & 0.32 bill. $\mathrm{m}^{3} /$ year \\
\hline 5 & Aquaculture & 7.5 bill. $\mathrm{m}^{3} /$ year \\
\hline
\end{tabular}

\begin{tabular}{lll}
\hline No. & Water Demand Forecast to 2020 & \\
\hline 6 & Deacidification, desalination & $0.6 \mathrm{bill.} \mathrm{m}^{3} /$ year \\
Total A & & $23.77 \mathrm{bill.m} /$ year \\
$\mathrm{B}$ & Red river's health & \\
1 & Environmental flow $(15 \% \mathrm{~A})$ & $3.56 \mathrm{bill} . \mathrm{m}^{3} /$ year \\
\hline
\end{tabular}

Compare the results of three study researches: (i) Project 1: Planning using integrated water Red River Basin [10]; (ii) Project 2: Scientific basis and operating practices for water supply in dry season of RRD [11]; (iii) Project 3: $2^{\text {nd }}$ Red River Basin [12] regarding water demand of economic sectors in the territory of Vietnam by 2020 as Figure 1.

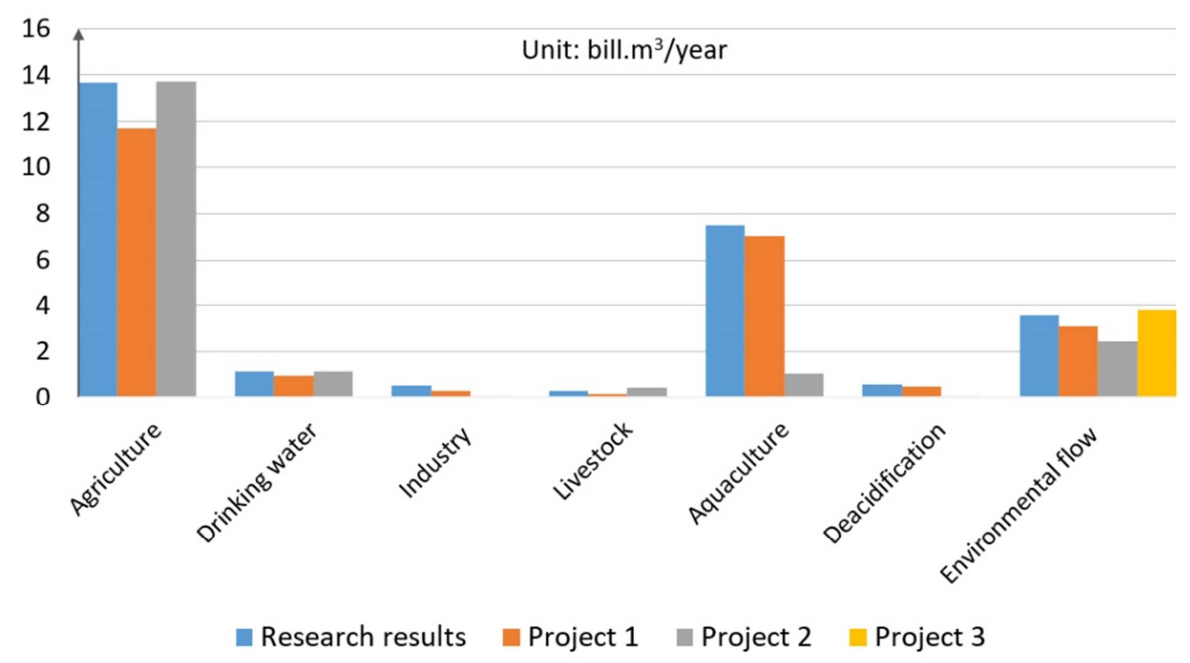

Figure 2. Comparing calculation results regarding the water demand on charts with data from different three projects.

Comparative charts as Figure 2 show that the results of calculations on water demand for economic sectors in the RRD of this study did not differ significantly from the previous studies.

These results show that total water demand of the economic sectors in the RRD by 2020 is estimated at 23.77 bill. $\mathrm{m}^{3} /$ year. In comparison with water demand of other sectors, agriculture production is largest; it is about $13.65 \mathrm{bill} . \mathrm{m}^{3} /$ year, accounted for $16.4 \%$ of total annual flow of Red river in Vietnam.

\subsection{Assessing the Status Quo of the Performance Assessment of Irrigation Schemes in RRD}

The Benchmarking Index (as Table 3) was conducted for 33 irrigation schemes in the whole RRD including 10 provinces: Hanoi, Hai Duong, Hai Phong, Thai Binh, Nam Đinh, Ninh Binh, Hung Yen, Ha Nam, Vinh Phuc and Bac Ninh; The results are shown in Table 5.

Table 5. Assessment results of efficient management of irrigation schemes according to the Benchmarking Index (2015).

\begin{tabular}{|c|c|c|c|c|}
\hline Symbol & Benchmarking & Average Value in RRD & Average Value in Vietnam & Unit \\
\hline $\mathrm{C} 1$ & Cost for operating, maintenance and repairs & $1,138,000$ & 758,000 & $\mathrm{VNĐ/ha}$ \\
\hline $\mathrm{C} 2$ & Rate of solidification canals & 35.22 & 48.74 & $\%$ \\
\hline $\mathrm{C} 3$ & Water monitoring & 52.56 & 59.52 & $\%$ \\
\hline $\mathrm{C} 4$ & Construction saftify & 20.10 & 30.18 & $\%$ \\
\hline N1 & Irrigation levels & 6,117 & 8,455 & $\mathrm{~m}^{3} / \mathrm{ha}$ \\
\hline $\mathrm{N} 2$ & On-farm irrigation water use & 4.697 & 5.510 & $\mathrm{~m}^{3} / \mathrm{ha}$ \\
\hline N4 & Irrigation efficiency compare with original designs & 63.46 & 54.88 & $\%$ \\
\hline N5 & Irrigation efficiency compare with plan & 100 & 100 & $\%$ \\
\hline N6 & External demand for agricultural production & 11.10 & 14.61 & $\%$ \\
\hline N7 & Drainage efficiency for agriculture & 94.71 & 92.72 & $\%$ \\
\hline $\mathrm{K} 1$ & Number of labor management & 125 & 1.090 & ha/person \\
\hline $\mathrm{K} 2$ & Management skills of IDMC & 70.17 & 71.06 & $\%$ \\
\hline $\mathrm{K} 3$ & Management skills of workers & 69.78 & 63.67 & $\%$ \\
\hline
\end{tabular}




\begin{tabular}{|c|c|c|c|c|}
\hline Symbol & Benchmarking & Average Value in RRD & Average Value in Vietnam & Unit \\
\hline K4 & The cost ratio of irrigation schemes & 101 & 98.33 & $\%$ \\
\hline K5 & The cost ratio of labor of irrigation schemes & 41.45 & 42.63 & $\%$ \\
\hline K6 & The cost ratio of O\&M of irrigation schemes & 21.89 & 64.58 & $\%$ \\
\hline M1 & Irrigation water quality & - & - & - \\
\hline $\mathrm{T} 1$ & Density of on-field channel & 125 & 1.090 & $\mathrm{~km} / \mathrm{ha}$ \\
\hline $\mathrm{T} 2$ & Farmers participation in water management & 70.17 & 71.06 & $\mathrm{VNĐ/ha}$ \\
\hline $\mathrm{T} 4$ & The cost ratio of water fee collection & 101 & 98.33 & $\%$ \\
\hline
\end{tabular}

* WUOs: Water user organizations.

\subsection{Assessing the Drainage Water Quality at Two Drainage Gates Along the Red River}

According to the monitoring results of the Centre for Evaluation and Monitoring (CEM) belongs to Ministry of Natural Resources and Environment (MONRE) of Vietnam [15], showed at some points near the drainge gates of irrigation schemes along the Red river have some characteristics:

i) Pollution by suspended solids, organic matter $\left(\mathrm{BOD}_{5}\right.$, COD reached from 1.3 - 3.7 times the permitted standard), dissolved oxygen (DO reached 1:11 1.02 - fold), nutrients (Ammonium), microorganisms (Coliform reached 1.17 - 2 times), chemicals and heavy metals (such as Phenol, As, Fe) and plant protection chemicals (Aldrin, 4.4 'DDT).

ii) Indicators $\mathrm{NO}_{2}$ and $\mathrm{NO}_{3}$ also tend to increase and reached the highest levels in the drainage position of the irrigated area.

- Indicators phosphate, oil exceeded the permitted level 1.1 - 1.5 times compare with QCVN 08:2008/BTNMT regarding "National technical regulation on surface water quality".

\section{Discussion}

The value of N4 indicator at the Table 5 has value is $63.46 \%$, mean that is the irrigation efficiency of irrigation works is estimated at about $60 \%$ compared with design. Beside that, the
$\mathrm{N} 2$ indicator is present the on-farm water use level (about $4,700 \mathrm{~m}^{3} / \mathrm{ha}$ ) of existing irrigation works reach approximately $77 \%$ of the total volume of $\mathrm{N} 1$ indicator - irrigation water supplied at the beginning of system (reaching $6,100 \mathrm{~m}^{3} / \mathrm{ha}$ ); thus, the loss of water during water transmission from the head works to the farms is still relatively high, up to $23 \%$. The effectiveness of irrigation schemes in RRD has not yet achieved as original designs due to some reasons:

i) Most of hydraulic works have been built about 40 years ago, therefore, these works has now been degraded over time.

ii) Poor management and operation of the Irrigation and Drainage Management Companies (IDMCs).

iii) Lack of budgets to upgrade, repair and maintenance the hydraulic works.

According to calculation results at Table 4, to forecast in 2020, only for agricultural production, the Red River needed to be supplied amount of water is about $21.5 \mathrm{bill} . \mathrm{m}^{3} /$ year, increase 8 bill. $\mathrm{m}^{3} /$ year compared to actual demand (13.65 bill. $\mathrm{m}^{3} /$ year); and millions of cubic meter of irrigation water for other economic sectors (such as fisheries, industry, handicrafts, livestock, etc) will also create a lot of pressure on the irrigation schemes along the Red river. To meet the increasing water demand for agriculture production and other economic sectors by 2020, hydraulic works will have to receive more water from the Red River (Figure 3), this trade-offs would be a negative impact of the Red river health.

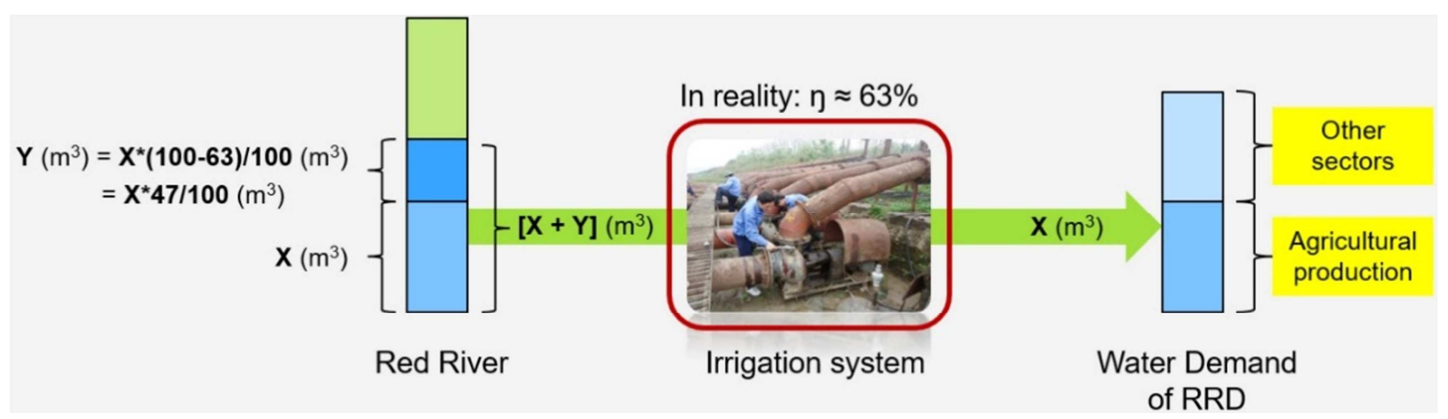

Figure 3. The actual water requirements to be taken from the Red river to provide future agriculture water demands (2020) in the RRD.

Continued from analyzing as mentioned above, not all the irrigation water will be "disappear" completely, after being used partly for human productive activities, especially agriculture production, majority of irrigated water will be back to the Red River by many ways, such as via the drain-age canals or groundwater. Unfortunately, most irrigation supplies contain very high concentrations of these toxic and are generally quite big problems, which are the water quality and salinity intrusion as Figure 4. 


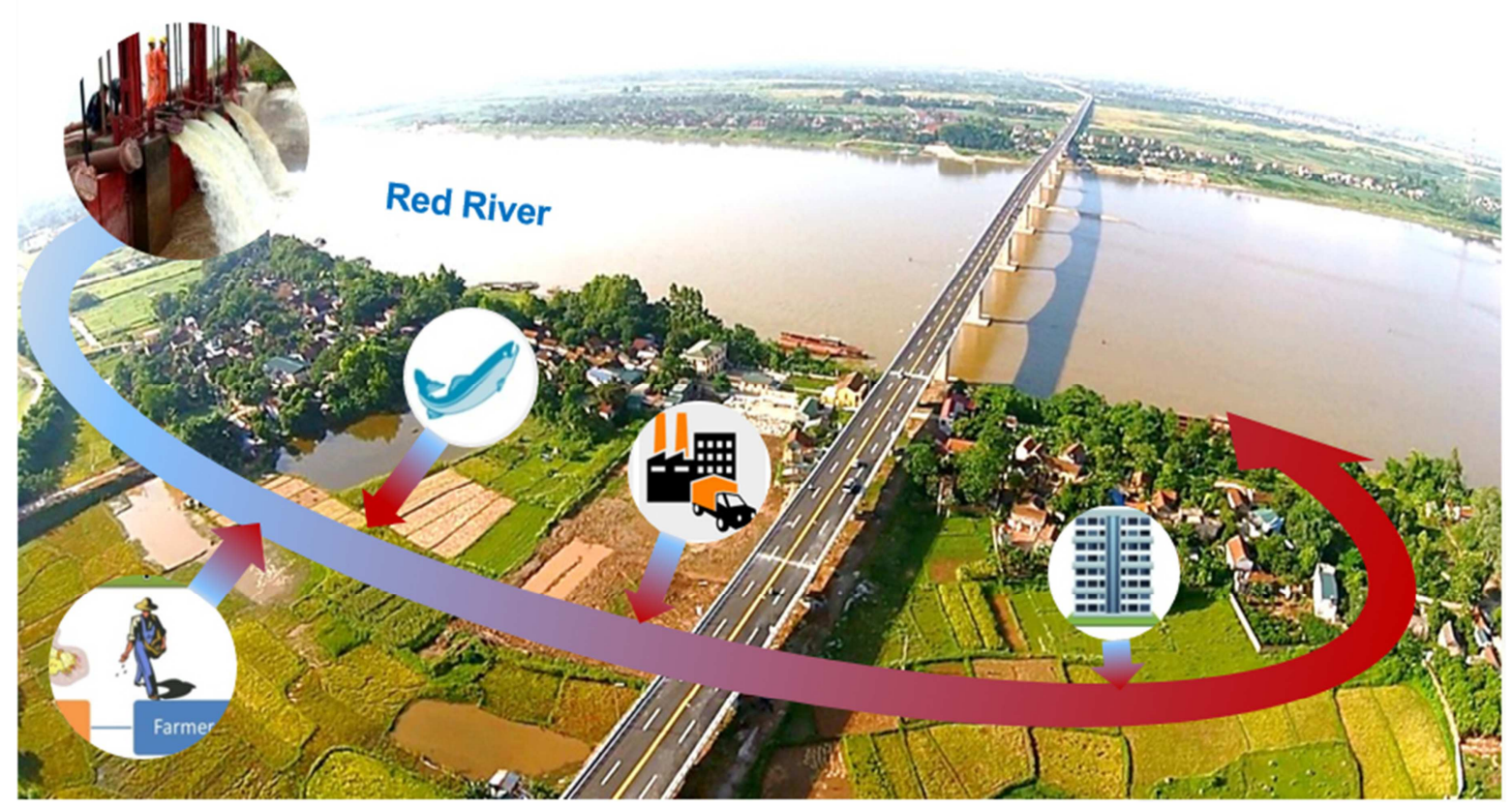

Figure 4. Relationship between irrigation schemes and Red river.

A more detailed analysis of water pollution issues raised in the Red river as follows:

1) The water quality: after water is used in the irrigated lands, it will drain back to the Red river, and irrigated water carries a lot of the residual of plant protection products, fertilizer on the field, waste discharge from handicraft villages, industry parks, etc.; these results show through the $\mathrm{BOD}_{5}, \mathrm{COD}$, DO, Coliform, etc. indicators exceeds the permissible standards in the drain gates of irrigation schemes along the Red river (Item 3.2); in consequence, poor water quality and pollution have negative impact on ecological characteristics of the Red river. It's also leading to the affecting the livelihood of local people, the fishery resources decline will directly affects all fishermen in fishing villages, furthermore, those living along the two sides of the Red river, when their crop production will be reduced due to irrigation water pollution. Furthermore, which is affecting human health, if the communities living along the Red river used contaminated water for domestic purposes will cause serious diseases related to stomach, nervous system, reproductive, skin, etc especially cancer diseases.

2) The salinity intrusion: use more water for irrigation systems along the Red river leads to lack of water to push salinity in the estuaries, so the combined effects of salinity intrusion and sea level rise (due to climate change) resulted in degradation of coastal ecosystems.

In summary, more irrigation water may be more harmful for the Red River health, that is absolutely correct in the context of the hydraulic works also supply for other economic sectors such as industry, drinking water, aquaculture farms, etc. Frankly, there is an assumption, many environmental protection agencies of Government and NGOs will protest, therefore, this trade-off usually involves the irrigation systems will have to use less water from the Red
River, in consequence, not getting enough water to service agriculture production and other economic sectors lead to impact on development of RRD.

Therefore, to harmonize the benefits between the sustainability of water supply and the Red river health, one of the approaches to solve these problems, which is improving irrigation water use efficiency of the irrigation schemes in RRD. The solutions group to repair, upgrade, and modernize irrigation schemes often require a huge cost, up to billions of US\$, which surpasses the affordability of the national budget, but if the delay in the repairing and upgrading, the hydraulic works will continue to deteriorate.

Every year, the Vietnam Government has a policy to support irrigation fees for water users (focus on the farmer) in the RRD through the IDMCs, estimated at 2,100 billion VND [16]. However, the budget above-mentioned is fixed over a long time period (normally, 3 - 5 years), therefore, with unfavorable weather factors (storms, floods, cyclones, etc.) and wage costs up to $70 \%$ of the irrigation fee subsidy for a large number of officers and employees (14,000 people) of IDMCs in the RRD, after deductions other expenses, normally, only $18-21 \%$ of the total water service charge (about 420 billion VNĐ - 200 million US\$) is used to repair and upgrade thousands of irrigation works, this is an impossible mission and this vicious circle will lead to a deeper impact on the ecosystems and livelihoods of the people living along the Red river as analyzed above. Thus, the nature of the problem to be solved is need to ensure financial resources for the IDMCs (including operation, maintenance, upgrading, repairing and modernization of irrigation schemes).

Therefore, need a breakthrough policy to break the barriers of current irrigation policy. Accordingly, the policy proposed in this study is to make a transition from public irrigation 
services to irrigation service pricing, to convert irrigation water into a commodity, and to be influenced by market factors. The water pricing of irrigation services is a new approach in Vietnam, if applied, it will open up a new financing mechanism in the field of irrigation sector; It also requires IDMCs to collect the enough water fees from the water users (WUs). WUs also have the right to refuse to pay irrigation services if the IDMCs fail to meet the terms and conditions in the contract. However, there should be a roadmap to collect the irrigation service pricing of the WUs, the hypothesis of 03 options as follows:

i) Option 1A: To maintain and continue implementing the irrigation fee support policy.

ii) Option 1B: Immediately turning to the principle of market economy for irrigation service pricing is "correctness calculation - adequacy calculation" and "proper collection enough collection" of WUs.

iii) Option 1C: Conversion from irrigation fee subsidy to irrigation service pricing, but the State still partly subsidizes irrigation service.

The SWOT analysis for three options above-mentioned shows that policy change from irrigation fees to irrigation services is an indispensable trend that needs to be made to access the market mechanism. Although some IDMCs also commented that the continuation of the irrigation support policy under Option 1A was the optimal solution to maintain the irrigation systems with minimum funding to service agricultural production, ensuring food security for the whole region. However, the results of the SWOT analysis for both options 1B and 1C show the high feasibility of applying irrigation service pricing in the Red River Delta, but the new mechanism should be implemented along a roadmap as suggested in Option 1C, the reason is that to avoid the risk of implementing the irrigation service pricing regime such as a sharp increase in input costs in agricultural production, it would be a shock for millions of WUs or the WUs will seek to break the crop planning, switch to super-profitable crops. Forecasting impacts under Option $1 \mathrm{C}$ is clearly illustrated by the fact that when IDMCs have sufficient funds to maintain the operation, repair and upgrading of hydraulic works, besides saving about 2,100 billion VNĐ annually for the State budget, irrigation systems would also reduce 8 billion cubic meters of irrigation water (for agricultural production) from the Red River compared to actual demand by 2020 , therefore, it is also reduce the water pollution from irrigation schemes, contributing to minimize negative impacts on the environment and ecosystems of the Red river.

Expected results will motivate: (i) IDMCs will be achieved self-control in managing and operating costs; (ii) Ensuring budget for maintenance, repairing and modernization of hydraulic works, improving the operational efficiency of RRD's irrigation schemes compared to the current rate $(63 \%)$; (iii) WUs are aware of economical and efficient use of irrigation water; (iv) Meet multi-purpose water supply requirements for non-agricultural production sectors; (v) Reducing negative impacts on the Red river ecosystem; (vi) Reduce the annual burden from the State budget to support irrigation fees for WUs.

\section{Conclusions}

Compare the values of the water use demand and effectiveness of irrigation schemes in RRD shows that water supply for agriculture production will increase dramatically

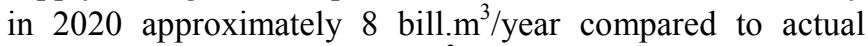
demand is about 13.65 bill. $\mathrm{m}^{3} /$ year; more irrigation water may be more harmful for the Red River health. That is absolutely correct in the context of the hydraulic works not only provide irrigation water for agriculture production, which also supply for other economic sectors such as industry, drinking water, aquaculture farms, etc. Therefore, to harmonize the benefits between the sustainability of irrigation water supply and the Red river health, one of the approaches to solve these problems, which is transfer from irrigation fees policy to irrigation services mechanisms.

However, if Vietnam Government immediately replaces the irrigation fees policy by the irrigation services mechanisms, it can cause major disturbances in the production activities of millions of farmers; the increasing in input costs, particularly the cost of irrigation services in agricultural production. Through the SWOT analysis, the study suggests that Vietnam Government should continue to support a part of irrigation service fees; the irrigation service pricing will be reduced over the next years follows a roadmap and it will be ended when WUs have enough economic conditions to pay for all the cost of irrigation water in agricultural production.

\section{References}

[1] Department of Water Resources Management, "National Environment Report 2012 - Surface water environment," Ministry of Natural Resources and Environment of Vietnam, Hanoi, Vietnam, pp. 3-8, 2012.

[2] T. T. Nghia, "Flood management flood management in the Red - Thai Binh River Basin, Viet nam," Institute of Water Resources Planning of Vietnam, Hanoi, Vietnam, pp. 2-3, 2006.

[3] N. T. Nga, "Green transportation oriented management of road networks in provincial cities of type in the Red River Delta," Hanoi Archtectural University, Hanoi, Vietnam, p. 8, 2017.

[4] IGU/LUCC North East Asia Conference 2009, "Land cover and land use change in North East Asia: Problems of sustainable nature management," International Geographical Union, Vladivostok, Russian, pp. 45-46.

[5] N. Van Diep, N. H. Khanh, N. M. Son, and N. Van Hanh, "Integrated water resources management in the Red River Basin - Problems and Cooperation opportunity," Paper presented at the International conference on Adaptive and Integrated water management, Basel.

[6] P. T. Anh and K. Shannon, "Water Management in Vietnam Indigenous Knowledge and International Practices: The Case of the Red River Delta," Northern Hydraulic Planning Institute of Vietnam, Hanoi, Vietnam, pp. 1-3, 2010. 
[7] Directorate of Water Resources, "Approving the survey on management, exploitation and use of irrigation schemes," Ministry of Agriculture and Rural Development of Vietnam, Hanoi, Vietnam, pp. 2-9.

[8] Ministry of Agriculture and Rural Development, "70 years 1945-2015, irrigation schemes in Vietnam," Labour Publishing House, Hanoi, Vietnam, pp. 17-23.

[9] N. D. Viet and D. T. Tu, "Rationale for implementing the irrigation management transfer that aim to improve efficiency of water supply and river's health case study: Red River Delta," International Conference: Mekong, Salween and Red Rivers: Sharing Knowledge and Perspectives Across Borders, Faculty of Political Science Chulalongkorn University, Bangkok, Thailand, pp. 2-3.

[10] C. Jolk, S. Greassidis, S. Jaschinski, H. Stolpe, and B. Zindler, "Planning using integrated water Red River Basin," University of Bochum, Bochum, Germany, pp. 711-725.

[11] L. K. Truyen, "Scientific basis and operating practices for water supply in dry season of Red River Delta," Ministry of Science and Technology of Vietnam, Hanoi, Vietnam, pp. 4560, 2008 .

[12] Asian Development Bank, "PCR Viet Nam - Second Red River Basin Sector Project," Ministry of Agriculture and Rural Development of Vietnam, Hanoi, Vietnam, 2012.

[13] W. Gretzky, "Strategic planning and SWOT analysis," Health Administration Press, Canada, pp. 91-97, 2010.

[14] Directorate of Water Resources, "Benchmarking - Decision No. 2212/QĐ-BNN-TCTL," Ministry of Agriculture and Rural Development of Vietnam, Hanoi, Vietnam.

[15] Centre for Evaluation and Monitoring, "Environmental water report," Ministry of Natural Resources and Environment of Vietnam, Hanoi, Vietnam, pp. 67-100, 2014.

[16] Directorate of Water Resources, "Water fee report," Ministry of Agriculture and Rural Development of Vietnam, Hanoi, Vietnam, 2015. 